\title{
The lectin of the bark of European spindle (Euonymus europaeus $L$.): purification, physico-chemical characteristics and application in histochemical studies
}

\author{
O. R. Vrubel ${ }^{1}$, E. A. Sogomonian 1 , V. O. Antonyuk ${ }^{1,2}$ \\ ${ }^{1}$ Danylo Halytsky Lviv National Medical University \\ 69, Pekarska Str., Lviv, Ukraine, 79010 \\ 2 Institute of Cell Biology, NAS of Ukraine \\ 14/16, Drahomanov Str., Lviv, Ukraine, 79005 \\ antonyukvo@gmail.com
}

\begin{abstract}
Aim. The purification of lectins from the bark and seeds of E. europaeus $L$. assessment of comparative characteristics of their carbohydrate and histochemical specificity, evaluation of the feasibility of replacing seed lectin with lectin of the bark of E. europaeus L. Methods. Salting out of $\mathrm{NaCl}$ lectins, ion-exchange chromatography on DEAE-Toyopearl and affinity chromatography on cross-linked ovomucin, electrophoretic purity studies in PAAG, comparative study of the immunochemical and histochemical properties of bark and seed lectins. Results. A lectin found in the bark of the European spindle does not differ in carbohydrate specificity from seed lectin. A method has been developed for purifying the found lectin by salting out $\mathrm{NaCl}$, ion-exchange chromatography on DEAE-Toyopearl and affinity chromatography on cross-linked ovomucin by elution with borate buffer solution $(\mathrm{pH} 9.0-9.8)$ in the temperature range $+30-+55^{\circ} \mathrm{C}$. Electrophoretic purity for lectin from bark was studied and the immunochemical properties of the lectins from bark and seeds were compared. A histochemical study of the binding of bark lectin and European spindle seeds lectin to glycoconjugates of mammalian tissues showed that both lectins bind to the same histological structures. However, bark lectin has an advantage over seed lectin in a simpler purification method (lack of seed degreasing procedure) and in the possibility of harvesting raw materials for a whole year. The dynamics of changes in the hemagglutinating activity of lectins in the organs in the European spindle during the annual vegetative cycle of the plant was also studied, which made it possible to choose the optimal time for harvesting raw materials for the purification of this lectin.
\end{abstract}

Ke yword s: European spindle, Euonymus europaeus L., lectins, carbohydrate specificity, purification, properties.

(C) 2020 O. R. Vrubel et al.; Published by the Institute of Molecular Biology and Genetics, NAS of Ukraine on behalf of Biopolymers and Cell. This is an Open Access article distributed under the terms of the Creative Commons Attribution License (http://creativecommons.org/licenses/by/4.0/), which permits unrestricted reuse, distribution, and reproduction in any medium, provided the original work is properly cited 


\section{Introduction}

Lectins are a complex and heterogeneous group of non-enzymatically carbohydratebinding proteins that specifically recognize and bind reversibly to specific mono- and oligosaccharides on cell surfaces, the extracellular matrix, and secreted glycoproteins. Lectins bind carbohydrates and have the ability to agglutinate cells and precipitate polysaccharides and glycoconjugates. Vegetable lectins have been known as early as the late nineteenth century. They were classified according to their carbohydrate specificity. However, today, due to the significant development of molecular biology, it is possible to classify all lectins according to their molecular structure and evolutionary affinity. By the beginning of the 21 st century, seven families of plant lectins had already been isolated, but lectins from E. europaeus $L$. seeds were not among them. Applying a complex of biochemical, molecular, and cell-biological approaches, it has been shown [1] that this lectin is representative of a new, eighth family of plant lectins not related to previously known ones. Schmidt was the first to report the presence of lectin in extracts from E. europaeus L. seeds in 1954, but the interaction of this lectin with monoand oligosaccharides was studied in detail by Petryniak et al. in 1977 [2]. It was found that the center of binding of carbohydrates in the Euonymus europaeus lectin has a considerable length and is complementary to the carbohydrate of the following structure:

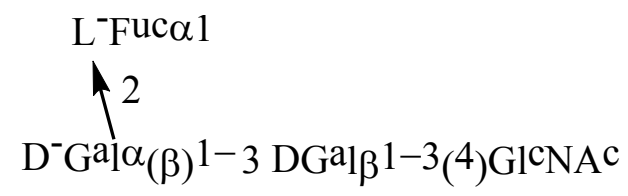

Unlike highly specific anti-B lectins, it does not clearly differentiate the $\alpha$ and $\beta$ bond of terminal D-galactose, which may be the cause of cross-reaction with group-specific substance $\mathrm{H}$ on the surface of human red blood cells $(\mathrm{O})$.

Revision of the data obtained using a glycan array confirmed a high reactivity of Euonymus europaeus lectin against the group B oligosaccharides but also revealed binding to mannoserich $\mathrm{N}$-glycans [1, 3, 4].

Euonymus europaeus lectin has been used in histochemical and cytochemical studies, in particular as a marker of endothelial cells in normal and in tumors [5]. It was one of the best markers for determining the pluripotent status of stem cells that can be used for quality control in cell therapy and regenerative medicine [6]. E. europaeus seed lectin revealed differences in salivary and serum glycoprotein composition in healthy humans and patients with a latent form of Keshan's disease (highflying cardiomyopathy) [7].

The extracts of the plant bark are also characterized by high hemagglutinating activity, but this lectin has not been described in the literature. Obtaining lectin from the bark may have several advantages over purification from the seeds, in particular, the bark of the plant can be harvested throughout the year, unlike fruits that are available only in the fall. However, we must be sure of the identity of the carbohydrate specificity of these two lectins and the presence of lectin in the bark at different growing seasons. According to the literature, the physicochemical properties, carbohydrate specificity, and biological properties of lectins found in different organs of the same 
plant may differ. For example, the carbohydrate specificity of bark and seeds lectins of Laburnum anagyroides Medik is significantly different [8].

The aim of this work was to purify lectins from the bark and seeds of E. europaeus $L$. to compare their carbohydrate and histochemical specificity and to evaluate the expediency of replacing lectin from the seeds on lectin of the E. europaeus $L$. bark.

\section{Materials and Methods}

\section{Investigation of the influence}

of the vegetation phase on

the hemagglutinating activity of lectins in plant organs

The bark, stems, leaves and seeds of spindle tree (Euonymus europaeus L.) were harvested during the annual cycle of vegetation from the same plant on the outskirts of Lviv with an interval of 10 days, and during the period of rapid changes in the activity of lectins - every 3-5 days. Taking into account possible daily fluctuations, the samples were taken between 15 and 17 o'clock. The dried at room temperature raw materials were ground and extracted with $0.9 \%$ sodium chloride solution in a ratio of 1: 5 (for bark and seeds) and 1:2 (for leaves) for $3 \mathrm{~h}$ at room temperature.

The activity of lectins in the material was determined by the titer of hemagglutination of human red blood cells by the method described earlier [8].

\section{Purification of lectins from the seeds and bark}

Euonymus fruits were harvested in the fall (September-October) after full ripening. The pericarp was separated from the seeds and removed by sieving through appropriate sieves and manually. They were then crushed in an electric mill, and the resulting powder was sieved through a sieve with $d=1 \mathrm{~mm}$. The sieved powder was poured with hexane in a ratio of 1: 10 and stirred continuously with a mechanical stirrer for $30 \mathrm{~min}$. The extractant was then pressed on the press and the low-fat flour was dried at room temperature for bark and seeds. After drying the powder from the seeds was used to purify the lectin. The subsequent stages of lectin purification were identical for bark and seeds.

The bark of spindle tree collected at any time of the year was ground to a particle of size less than $0.5 \mathrm{~mm}$ in diameter, then placed in a vessel with a stirrer, poured with $0.9-1 \%$ $\mathrm{NaCl}$ solution and stirred for $60 \mathrm{~min}$; the bark (seeds) to extractant ratio was 1: 8 . The resulting extract was clarified by centrifugation for $10 \mathrm{~min}$ at $5000 \mathrm{~g}$. The lectin from the extract was concentrated by precipitation of $\mathrm{NaCl}$ at almost complete saturation of the salt $(300 \mathrm{~g} / 1)$. The sediment containing lectin was collected by centrifugation for $20 \mathrm{~min}$ at $8000 \mathrm{~g}$ or by filtration. Then it was dissolved in water and dialyzed against tap water. The formed precipitate was removed, the solution filtered and applied to a column of DEAE-Toyopearl equilibrated with $0.05 \mathrm{M}$ phosphate buffer, $\mathrm{pH}$ 7.0. The column was washed with the same buffer solution, and then the ionic strength of the solution was increased to $0.2 \mathrm{M}$. The output of lectin from the column was controlled by the reaction of hemagglutination of human erythrocytes of group B (III) or O (I).

The fractions containing hemagglutinating activity were pooled and purified lectin was 
precipitated by $\mathrm{NaCl}(300 \mathrm{~g} / \mathrm{l})$. The formed precipitate was centrifuged, dissolved in a small volume of water, and after a short dialysis (2-3 h) against distilled water, a $1 \mathrm{M} \mathrm{NaCl}$ column filled with affinity sorbent was washed. Cross-linked ovomycin was used as an affinity sorbent [9].

After the lectin solution enters the gel, the latter was washed from the ballast proteins with $1 \mathrm{M}$ sodium chloride solution. The lectin adsorbed on the column was removed with $0.1 \mathrm{M}$ borate buffer solution, $\mathrm{pH} 9.0-9.8$, heated to $+30-+55^{\circ} \mathrm{C}$ (Fig. 2).

The output of lectin from the column was monitored by Lowry reaction or spectrophotometrically at $280 \mathrm{~nm}$. The protein-containing fractions were combined, lectin was precipitated with sodium chloride or ammonium sulfate. The obtained lectin was stored in salt or freeze-dried after exhaustive dialysis against distilled water.

\section{Electrophoretic studies}

Molecular mass of polypeptide chains of the lectin was determined by electrophoresis in $15 \%$ polyacrylamide gel supplemented with $0.1 \%$ sodium dodecyl-sulfate [10]. The mixture of proteins with known molecular mass from "Fermentas" company (Olayne, Latvia) was used as standard.

The interaction of bark and seeds lectins of E. europaeus with erythrocytes of humans and animals was studied by determining the hemagglutination titer of $1 \%$ lectin solutions and using the washed from serum $2 \%$ human erythrocyte suspension of $\mathrm{O}, \mathrm{A}$ and $\mathrm{B}$ groups and of animals in buffered saline solution SFR). Human red blood cells were taken at the Lviv Regional Blood Transfusion Station, and rabbit, rat, mouse and guinea pig erythrocytes were from the vivarium of Lviv National Medical University. Duck and chicken erythrocytes were taken from a poultry farm.

The protocol of the study has been approved by the Ethics Committee of the Danylo Halytsky Lviv National Medical University (the protocol No. 2 dated February 15, 2016).

The animals behaved in accordance with the "General ethical principles of animal experiments consistent with the provisions of the" European Convention for the Protection of Vertebrate Animals used for Experimental and Scientific Purposes "(Strasbourg, 1986, as amended in 1998). Council of Europe 2010/63 / EU, Law of Ukraine No. 3447-IV "On Protection of Animals from Cruel Treatment".

Study of carbohydrate specificity of lectins

Carbohydrate specificity of the bark and seeds lectins was determined by the hemagglutination inhibition by carbohydrates and glycoproteins. Using a stepwise (twofold) dilution of a carbohydrate or glycoprotein, its minimum concentration was determined, which completely inhibited the activity of lectin diluted to a titer of $1: 4$ [8].

To characterize the carbohydrate specificity of the lectin we used: D-glucose, D-galactose, lactose, ("Soyuzhimreaktiv"), $\alpha$ - and $\beta$-methylD-galactoside, L-rhamnose, ("Chemapol”, Czech Republic), N-acetyl D -glucosamine ("Fluka", Switzerland), N-acetyl-D-galactosamine ("Chemapol", Czech Republic), D-mannose (manufactured by the Bratislava Chemical Institute, Slovakia), 4-nitrophenyl- $\beta$-D-glucoand galactoside, 4-nitrophenyl- $\beta$-D-glucosamine, ("Serva", Germany), L-fucose ("Koch Light", 
United Kingdom), $\alpha$-phenyl-N-acetyl-Dglucosaminopyranoside, 4-nitrophenyl- $\beta$ D-glucopyranoside, 4-nitrophenyl- $\alpha$ D-mannopyranose (Serva, USA).

To determine the interaction with glycoproteins and polysaccharides we used water-soluble starch, ovomycoid and ovalbumin three times recrystallized, inulin, yeast mannan, bovine thyroglobulin ("Biolar", Olaine, Latvia), gum arabic ("Loba Feinchemie"). Groupspecific substances $\mathrm{H}$, A and B were obtained from cystic fluid taken after ovarian surgery in patients with appropriate blood groups. Purification was carried out according to the method described previously [11].

\section{Histochemical studies}

The binding of the bark and seeds lectins to mammalian tissues glycoconjugates was studied using horseradish peroxidase-labeled lectins, prepared by the previously described method [9], on the endometrium of rats Wistar lines females in the diastral phase of the sexual cycle. Fixation of histological material was carried out in $4 \%$ neutral formalin, followed by paraffin pouring to make sections 5-7 $\mu \mathrm{m}$ thick. Visualization of lectin receptors was performed with 3,3'-diaminobenzidine tetrahydrochloride in the presence of hydrogen peroxide.

\section{Results}

Throughout the life cycle of the plant, the hemagglutinating activity of lectins varied over a fairly large range, but most clearly it was observed in the bark of spindle tree (E. europaeus L.).

The hemagglutination titer of the bark extracts increased sharply during the spring movement of the juices, reaching the highest level at the time of bud leaves opening. With the beginning of leaf development, it gradually decreased and was minimal at the time of their full development. At the beginning of seed maturation, the activity of lectins in the bark again increased to the maximum level, and subsequently decreased and remained the same during the rest period, until the beginning of the movement of juices.

As the fruit grows, the activity of lectins increases, reaching a maximum when the seeds ripen.

In leaves, the maximum activity of lectins was manifested in the buds. During the development of leaves, the lectin activity dropped to values near zero, and with the beginning of full functioning of the leaves rapidly increased to a certain level that remained constant during the growing season (Fig. 1).

The hemagglutination titer of the extracts was also influenced by the weather conditions and environmental factors. We found that the plants from well-lit places had a higher lectin and seed activity than those in shade.

The graph of purification of the Euonymus europaeus bark and seeds lectins obtained by ion-exchange chromatography (Fig. 2) shows that lectins began to leave the column when the ionic strength of the buffer solution increased to $0.1 \mathrm{M}$, but the bulk of the eluate was made up of ballast proteins. When the ionic strength of the buffer increased to $0.2 \mathrm{M}$, the bulk of the lectin was obtained.

The Euonymus europaeus lectins obtained by the ion exchange chromatography on DEAE-Toyopearl still need further purification. It was carried out by affinity chromatog- 


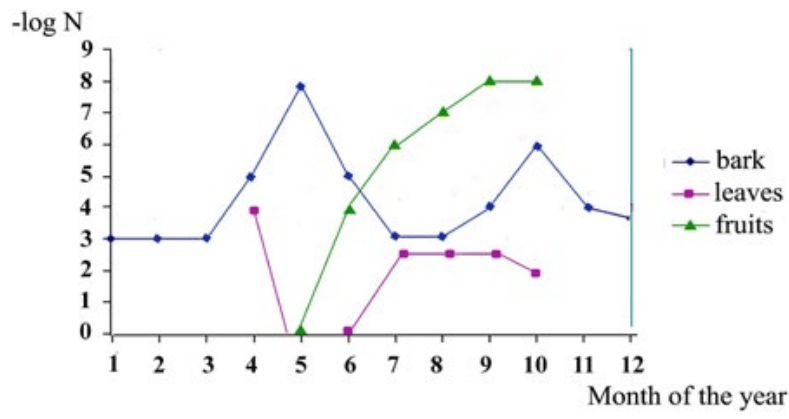

Fig. 1. Hemagglutination titer of E. europaeus L. extracts during the annual cycle of vegetation

Notes. The hemagglutination titer is denoted by the number $\mathrm{N}$ on the $\mathrm{y}$-axis, which corresponds to the tube number and the dilution of the extract 2-N times, when hemagglutination is still observed. The color lines indicate the titers of hemagglutination of erythrocytes of group I (0) human by extracts according to the bark, leaves and fruits of Euonymus europaeus $L$.

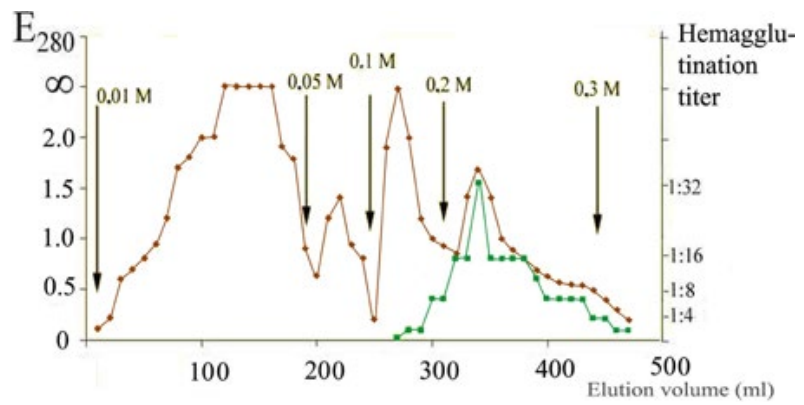

Fig. 2. Evonymus europaeus lectin purification procedure by ion-exchange chromatography

Notes: the tapes indicate the location of phosphate buffer solution, $\mathrm{pH} 7.0$; the molarity of the solution is given in figures

- The protein output is indicated in red

- Lectin hemagglutination titer in green

raphy on cross-linked glutaric aldehyde ovomucine (Fig. 3).

The need for application of heated buffer solution with $\mathrm{pH} 9.0$ to 9.8 is due to the strong sorption of lectin on the affinity sorbent. When heated, the buffer solution provides a faster

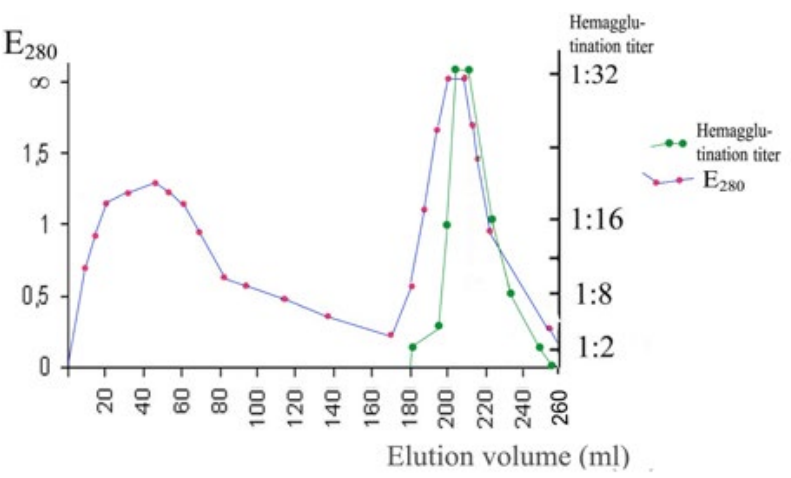

Fig. 3. Purification graph of Evonymus europaeus lectin by affinity chromatography

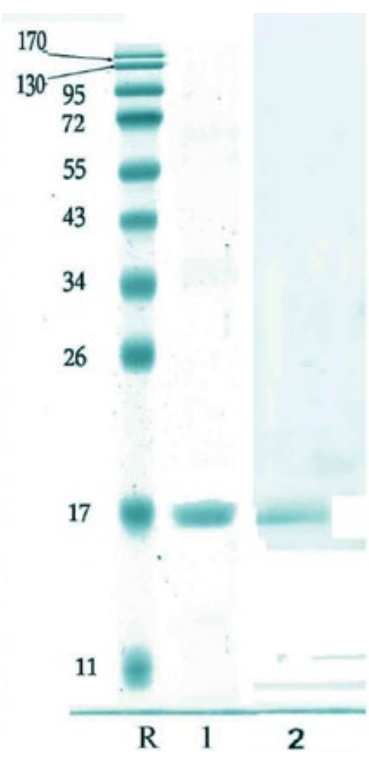

Fig. 4. Electrophoresis of the purified sample of $E u$ onymus europaeus bark lectin is shown in Fig. 4 (1) and electrophoresis of the Euonymus europaeus seeds lectin presented in Fig. 4 (2). A $15 \%$ PAGE was used, Tris- $\mathrm{HCl}$ buffer solution, $\mathrm{pH}$ 8.6 in the presence of $0.1 \%$ DDS-sodium salt. (R) placement of a standard mixture of protein markers of known molecular weight. The position of the subunits of purified bark lectin (line 1) and seed lectin (line 2) indicates that their molecular weights are the same and equal to $\approx 17 \mathrm{kDa}$.

and more concentrated elution of the lectin from the affinity sorbent.

The yield of lectin from the Euonymus europaeus bark collected in spring, according to our method of preparation was $13 \mathrm{mg} / \mathrm{kg}$ of air-dry raw material.

Lectins from the bark and from the seeds of Euonymus europaeus showed the same or 
The lectin of the bark of European spindle: purification, physico-chemical characteristics and application in histochemical studies

Table 1. Calculation of the purification efficiency of the bark lectin of Evonymus europaeus

\begin{tabular}{c|l|c|c|c|c|c|c|c|c}
\hline $\mathrm{N}$ & \multicolumn{1}{|c|}{ Stage of purification } & $\mathrm{V}(\mathrm{ml})$ & $\mathrm{C}(\mathrm{mg} / \mathrm{ml})$ & $\mathrm{T}$ & $\mathrm{V} \times \mathrm{T}$ & $\begin{array}{c}\mathrm{C} \times \mathrm{V}=\mathrm{m} \\
(\mathrm{mg})\end{array}$ & $\begin{array}{c}\text { Protein } \\
(\%)\end{array}$ & $\begin{array}{c}\text { Activity } \\
(\%)\end{array}$ & $\begin{array}{c}\text { Purification } \\
\text { efficiency }\end{array}$ \\
\hline 1 & Initial Extract & 1540 & 1.8 & $2^{-3}$ & 12320 & 2772 & 100 & 100 & 1 \\
\hline 2 & After NaCl precipitation (after dialysis) & 80 & 0.42 & $2^{-7}$ & 10240 & 33.6 & 1.2 & 83.1 & 69.25 \\
\hline 3 & Purification on DEAE-Toyopearl & 3.6 & 0.75 & $2^{-11}$ & 7373 & 2.7 & 0.097 & 59.8 & 616 \\
\hline 4 & Affinity chromatography & 2.6 & 0.72 & $2^{-11}$ & 5308 & 1.87 & 0.068 & 43.1 & 634 \\
\hline
\end{tabular}

Notes:

- For purification lectin, $150 \mathrm{~g}$ of air-dried bark were taken

- Activity (\%) - the result of division of VxT at the next stage by the initial VxT: $10240: 12320 \times 100 \%=83.1$

- The purification efficiency is determined by dividing the $\%$ activity output by the $\%$ protein output.

- The purification efficiency of the initial extract was taken as 1 .

very close physicochemical and immunobiological properties. This is evidenced by the electrophoresis in PAGE under denaturing conditions (0.1\% DDS-sodium salt) (Fig 4), the data of the study on the interaction with human and animal erythrocytes (Table 2), the study of carbohydrate specificity (Table 3 ) and the histochemical specificity of these lectins (Fig 5).

For both peroxidase-labeled lectins (Euonymus europaeus bark and seeds) in his-

Table 2. Investigation of the interaction of E. europaeus bark and seeds lectins with human and animal erythrocytes

\begin{tabular}{|c|c|c|c|}
\hline \multirow{2}{*}{ № } & \multirow{2}{*}{$\begin{array}{c}\text { The type of red blood } \\
\text { cells }\end{array}$} & \multicolumn{2}{|c|}{ The source of the lectin } \\
\hline & & bark lectin & seeds lectin \\
\hline 1 & Human, I (0) & $2^{-11}$ & $2^{-11}$ \\
\hline 2 & Human, II (A) & $2^{-8}$ & $2^{-8}$ \\
\hline 3 & Human, III (B) & $2^{-11}$ & $2^{-11}$ \\
\hline 4 & Rabbit & $2^{-15}$ & $2^{-15}$ \\
\hline 5 & Dog & $2^{-13}$ & $2^{-13}$ \\
\hline 6 & Rat & $2-8$ & $2^{-8}$ \\
\hline 7 & \begin{tabular}{|l|} 
Mouse \\
\end{tabular} & - & - \\
\hline 8 & Guinea pig & $2^{-3}$ & $2^{-3}$ \\
\hline 9 & Carp & - & - \\
\hline 10 & Duck & - & - \\
\hline 11 & Chicken & - & - \\
\hline
\end{tabular}

tological sections of the endometrium, their binding was observed in the following structures: superficial epithelium and epithelium of glands (apical part of cells), leukocytes located in the lamina, fibrous structures, especially peripheral areas of the endometrium, as well as in the cytoplasm of decidual cells. Leukocytes and fibrous structures gave a more intense positive response compared to superficial epithelium, gland epithelium, and decidual cells (Fig. 5).

\section{Discussion}

The results of histochemical studies indicate that the Euonymus europaeus L. bark lectin
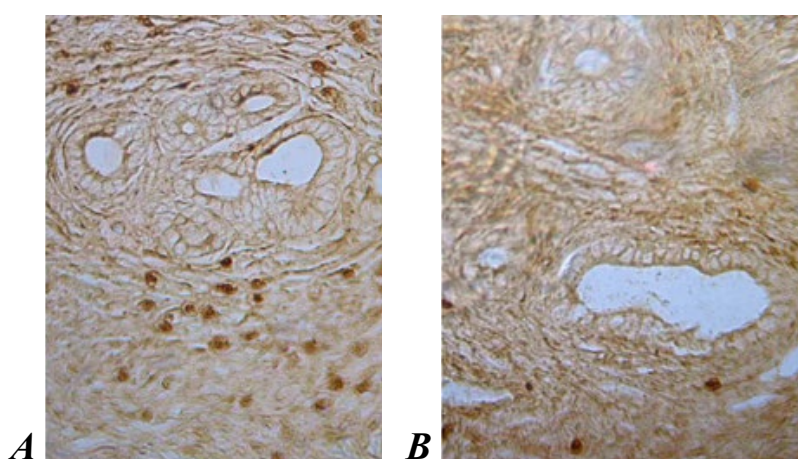

Fig. 5. Application of peroxidase-labeled bark lectin (A), seeds lectin (B) 
Table 3. Comparison of carbohydrate specificity of $E$. europaeus bark and seeds lectins

\begin{tabular}{|c|c|c|c|}
\hline \multirow[t]{2}{*}{ № } & \multirow[t]{2}{*}{ Carbohydrate } & \multicolumn{2}{|c|}{\begin{tabular}{|c|} 
Minimum concentration \\
of carbohydrate (mM) or \\
glycoprotein, which inhibits the \\
activity of 4 hemagglutinating \\
units of lectin
\end{tabular}} \\
\hline & & bark lectin & seeds lectin \\
\hline 1 & D-glucose & - & - \\
\hline 2 & D-galactose & - & - \\
\hline 3 & Maltose & - & - \\
\hline 4 & Lactose & 50 & 50 \\
\hline 5 & Saccharose & - & - \\
\hline 6 & $\begin{array}{l}\alpha \text {-methyl-D- } \\
\text { galactopyranoside }\end{array}$ & - & - \\
\hline 7 & $\begin{array}{l}\beta \text {-methyl-D- } \\
\text { galactopyranoside }\end{array}$ & - & - \\
\hline 8 & $\begin{array}{l}\alpha \text {-methyl-D- } \\
\text { mannopyranoside }\end{array}$ & - & - \\
\hline 9 & Ovariomycin H. & $0,03 \%$ & $0,03 \%$ \\
\hline 10 & Ovariomycin A & $0,125 \%$ & $0,125 \%$ \\
\hline 11 & Ovariomycin B & $0,004 \%$ & $0,004 \%$ \\
\hline 12 & $\begin{array}{l}\alpha \text {-phenyl-N-acetyl-D- } \\
\text { glucosamine }\end{array}$ & - & - \\
\hline 13 & \begin{tabular}{|l|} 
L-rhamnose \\
\end{tabular} & - & - \\
\hline 14 & Bovine salivomucin & $1 \%$ & $1 \%$ \\
\hline 15 & $\begin{array}{l}\text { N-acetyl-D- } \\
\text { galactosamine }\end{array}$ & - & - \\
\hline 16 & $\begin{array}{l}\text { N-acetyl-D- } \\
\text { glucosamine }\end{array}$ & - & - \\
\hline 17 & \begin{tabular}{|l|} 
Transferrin $1 \%$ \\
\end{tabular} & - & - \\
\hline 18 & Bovine thyroglobulin. & $1 \%$ & $1 \%$ \\
\hline 19 & Human IgG & $1 \%$ & $1 \%$ \\
\hline 20 & Yeast Mannan & - & - \\
\hline 21 & \begin{tabular}{|l|} 
L-fucose \\
\end{tabular} & - & - \\
\hline 22 & L-arabinose & - & - \\
\hline 23 & Ristomycin sulfate & $1 \%$ & $1 \%$ \\
\hline 24 & $\begin{array}{l}\text { 4-nitrophenyl- } \beta \text {-D- } \\
\text { glucopyranoside }\end{array}$ & $40 \mathrm{MM}$ & $40 \mathrm{MM}$ \\
\hline 25 & $\begin{array}{l}\text { 4-nitrophenyl- } \alpha-\mathrm{D} \text { - } \\
\text { manopyranoside } \\
\end{array}$ & - & - \\
\hline 26 & $\begin{array}{l}\alpha \text {-phenyl-N-acetyl-D- } \\
\text { glucopyranoside }\end{array}$ & - & - \\
\hline 27 & Cellobiose & - & - \\
\hline 28 & Pig liver glycogen & - & - \\
\hline 29 & Ovomucoid & $1 \%$ & $1 \%$ \\
\hline
\end{tabular}

can replace the seeds lectin. In terms of carbohydrate specificity, these lectins are almost identical. The advantage of bark lectin is an ability to harvest raw materials at any time of the year. However, the best time to prepare the bark, as a raw material for the purification of lectin, is phenophase, when the activity of lectins in the extracts of the bark increases several times. As can be seen from Fig. 1 during the spring movement of the juices the activity of the lectin in the bark of the plant is 32 times higher than during the winter rest period of the plant. From the raw materials collected during the spring it is possible to obtain the same amount of lectin as from the seeds. The advantage of obtaining lectin from the bark is also the absence of the need for degreasing raw materials, which reduces the number of steps in the lectin purification. There is a method of obtaining lectin from the Euonymus europaeus L. seeds by affinity chromatography on ovomucoid-Sepharose [1]. According to this method, lectin was obtained by treatment of crushed seeds with ethanol, subsequent extraction of raw material with 20 mm 1,3-diaminopropane, ion exchange chromatography of the purified filtrate on a $\mathrm{Q}$ Fast Flow column and gel chromatography on Sephacryl 100. The final purification of lectin is carried out by affinity chromatography on ovomucoid immobilized on Sepharose4B. The use of the bark of the plant instead of seeds as a raw material allows an extension of the timing of raw materials and a decrease of the number of stages of purification of the Euonymus europaeus lectin. Additionally noteworthy, the raw material base for the bark of the plant is much larger than for the seeds. We also used cross-linked ovomucoid for lectin 
purification. This sorbent is easier to obtain than ovomucoid-Sepharose. Moreover, it has a higher sorption capacity. We were the first to use ion exchange chromatography on DEAE-Toyopearl and then affinity chromatography as the last stage of purification of lectin. This sequence is due to the fact that, according to the literature, the bark of the Euonymus europaeus contains two chitin-binding monovalent lectins [12], which can interact with the residues of N-acetyl-D-glucosamine of ovomucoid. In the purification regimen proposed by us, chitin-binding lectins do not contaminate the target lectin product.

The role of lectins in plants is discussed in the literature. The function of lectins in plants is not investigated sufficiently. Based on the ability to selectively bind carbohydrates, the lectins can be involved in a variety of recognition processes: between different cells or cells and different molecules containing carbohydrates. The participation of lectins in the symbiosis of nitrogen-fixing bacteria and roots of legumes was investigated [13]. Symbiosis is specific in terms that a certain type of root bacteria can be associated only with a particular type of legume. Specific recognition of carbohydrate residues is crucial in protecting plants from various phytopathogens [14]. The amino acid sequence of Euonymus europaeus seed lectin shows high homology to stressdependent proteins derived from rice, so it has been suggested that this lectin may be formed by drought, high salt content, injury and treatment by some plant hormones $[1,3]$.

At the same time, the nature of changes in the activity of lectins in the bark, fruits and leaves of the plant during the annual vegetation cycle, which we investigated, indicates a pos- sible transport function of lectins. The significant increase in the activity of lectins in the bark extracts in the phenophase of the spring movement of the juices, the decrease of activity in the summer after the end of leaf growth and the re-increase of activity in the autumn until full maturation of the fruits indicate a possible transport of the necessary carbohydrate substances (carbohydrates and glycoproteins) for such processes.

\section{REFERENCES}

1. Fouquaert E, Peumans WJ, Smith DF, Proost P, Savvides SN, Van Damme EJ. The "old” Euonymus europaeus agglutinin represents a novel family of ubiquitous plant proteins. Plant Physiol. 2008;147(3):1316-24.

2. Petryniak J, Pereira ME, Kabat EA. The lectin of Euonymus europeus: purification, characterization, and an immunochemical study of its combining site. Arch Biochem Biophys. 1977;178(1):118-34.

3. Fouquaert E, Van Damme EJ. Promiscuity of the euonymus carbohydrate-binding domain. Biomolecules. 2012;2(4):415-34.

4. Agostino $M$, Velkov T, Dingjan T, Williams SJ, Yuriev E, Ramsland PA. The carbohydrate-binding promiscuity of Euonymus europaeus lectin is predicted to involve a single binding site. Glycobiology. $2015 ; 25(1): 101-14$.

5. Shangguan W, Fan C, Chen $X$, Lu R, Liu Y, Li Y, Shang Y, Yin D, Zhang S, Huang $Q$, Li X, Meng $W$, $X u$ H, Zhou Z, Hu J, Mo X. Endothelium originated from colorectal cancer stem cells constitute cancer blood vessels. Cancer Sci. 2017;108(7):1357-1367.

6. Toyoda M, Yamazaki-Inoue M, Itakura Y, Kuno A, Ogawa T, Yamada M, Akutsu H, Takahashi Y, Kanzaki S, Narimatsu H, Hirabayashi J, Umezawa A. Lectin microarray analysis of pluripotent and multipotent stem cells. Genes Cells. 2011;16(1):1-11.

7. Wang S, Fan Z, Zhou B, Wang Y, Du P, Tan W, Lammi MJ, Guo X. Roles of Glycoproteins in the Diagnosis and Differential Diagnosis of Chronic and 
Latent Keshan Disease. Molecules. 2017;22(5). pii: E746.

8. Antonyuk $V A$. Lectins and their raw materials sources. Lviv: "Quart”, 2005; 554 P.

9. Antonyuk VA A.S. USSR No. 1554961, A method of obtaining an affinity sorbent for purification of lectins IPC B 01 J 20/22, C 12 N 11/00, publ. 04.07.90 BI No. 13, 1990.

10. Maurer G. Disk-Electrophoresis. Moscow. "Mir", 1971; 55-102.

11. Lutsik AD, Detjuk ES, Lutsik MD. Lectins in Histochemistry. Lviv: "Lviv University edition”. 1989; 144 p.

12. Van den Bergh KP, Rougé P, Proost P, Coosemans $J$, Krouglova T, Engelborghs Y, Peumans WJ, Van Damme EJ. Synergistic antifungal activity of two chitin-binding proteins from spindle tree (Euonymus europaeus L.). Planta. 2004;219(2):221-32.

13. Wheatley RM, Poole PS. Mechanisms of bacterial attachment to roots. FEMS Microbiol Rev. 2018;42(4):448-461.

14. Lannoo N, Van Damme EJ. Lectin domains at the frontiers of plant defense. Front Plant Sci. 2014;5:397.

\section{Лектин кори бруслини європейської (Euоnymus europaeus $L$.): очистка, фізико-хімічні характеристики та застосування в гістохімічних дослідженнях}

О. Р. Врубель, Є. А. Согомонян, В. О. Антонюк

Мета. Очистка лектинів 3 кори та насіння E. europaeus $L$. та порівняльна характеристика їх вуглеводної та гістохімічної специфічності. Оцінка доцільності заміни лектину насіння лектином кори E. europaeus L. Методи. Висолювання лектинів $\mathrm{NaCl}$, іонообмінна хроматографія на ДЕАЕ-Тоуореаrl та афінна хроматографія на поперечно-зшитому овомуцині, дослідження елекрофоретичної чистоти в ПААГ, порівняльне дослідження імунохімічних та гістохімічних властивостей лектинів кори та насіння. Результати. У корі бруслини європейської знайдено лектин, який за вуглеводною специфічністю не відрізняється від лектину насіння. Розроблено спосіб очистки цього лектину шляхом висолювання $\mathrm{NaCl}$; іонообмінної хроматографії на ДЕАЕ-Тоуореarl та афінної хроматографії на поперечно-зшитому овомуцині за допомогою елюції боратним буферним розчином ( $\mathrm{pH} 9,0-9,8)$ в діапазоні температур $+30-+55^{\circ} \mathrm{C}$. У лектину досліджена електрофоретична чистота та здійснено порівняльне дослідження імунохімічних властивостей лектинів кори та насіння бруслини європейської. Гістохімічне дослідження зв'язування лектинів кори та насіння з глікокон'югатами тканин ссавців показало, що обидва лектини зв'язуються 3 одними і тими ж гістологічними структурами. Однак лектин кори має перевагу над лектином насіння у простішому способі очистки (відсутність процедури обезжирення насіння) та у можливості заготівлі сировини протягом цілого року. Також досліджено динаміку змін гемаглютинуючої активності лектинів в органах бруслини європейської протягом річного вегетаційного циклу рослини, що дозволило вибрати оптимальні терміни заготівлі сировини для очистки цього лектину.

К л юч о в і с л о в а: Бруслина європейська, Euonymus europaeus L., лектини, вуглеводна специфічність, очистка, властивості.

\section{Лектин коры бересклета европейского} (Euonymus europaeus L.): очистка, физикохимические характеристики и использование в гистохимических исследованиях

О. Р. Врубель, Е. А. Согомонян, В. А. Антонюк

Цель. Очистка лектинов из коры и семян $E$. europaeus $L$. и сравнительная характеристика их углеводной и гистохимической специфичности. Оценка целесообразности замены лектина семян лектином коры E. europaeus L. Методы. Высаливание лектинов $\mathrm{NaCl}$, ионообменная хроматография на ДЭАЭToyopearl и аффинная хроматография на поперечно-сшитом овомуцине, исследования елекрофоретической чистоты в ПААГ, сравнительное исследование иммунохимических и гистохимических свойств лектинов коры и семян. Результаты. В коре бересклета европейского найдено лектин, который по углеводной специфичностью не отличается от лектина семян. Разработан способ очистки этого лектина путем высаливания $\mathrm{NaCl}$; ионообменной хроматографии на 
The lectin of the bark of European spindle: purification, physico-chemical characteristics and application in histochemical studies

ДЭАЭ-Тоуореarl и аффинной хроматографии на поперечно-сшитом овомуцине с помощью элюции боратный буферным раствором (pH 9,0 - 9,8) в диапазоне температур $+30-+55^{\circ} \mathrm{C}$. У лектина исследована электрофоретическая чистота и осуществлено сравнительное исследование иммунохимических свойств лектинов коры и семян бересклета европейского. Гистохимическое исследование связывания лектинов коры и семян бересклета европейского с гликоконьюгатами тканей млекопитающих показало, что оба лектина связываются с одними и теми же гистологическими структурами. Однако лектин коры имеет преимущество над лектином семян в более простом способе очистки (отсутствие процедуры обезжиривания семян) и в возможности заготовки сырья в течение целого года. Также исследована динамика изменений гемагглютинирующей активности лектинов в органах бересклета европейского течение годового вегетационного цикла растения, что позволило выбрать оптимальные сроки заготовки сырья для очистки этого лектина.

Ключевы е слова: Бересклет европейский, Euonymus europaeus L., лектины, углеводная специфичность, очистка, свойства.

Received 18.11.2019 